\title{
TREATING ARUGULA SEEDS WITH ASCOPHYLLUM NODOSUM E AZOSPIRILLUM BRASILENSE IN VILHENA, RONDÔNIA
}

SILVA, Mateus Rocha da SANTOS, Elonha Rodrigues ${ }^{1}$ MOREIRA, Andressa Gregolin ${ }^{1}$

\begin{abstract}
SUMMARY: Information that seeks biological alternatives in arugula cropping are scarce in Rondônia state cultivation of arugula. The objective of this study was to evaluate the agronomic characteristics of arugula as a function of seed inoculation with Azospirillum brasilense, algae extract (Ascophyllum nodosum) and co-inoculation (A. nodosum with A. brasilense) in Vilhena, Rondônia, Brazil. The experiment was carried out from March to April 2018, at the Faculdade da Amazônia, Vilhena, Rondônia, Brazil. The experimental design was completely randomized with four treatments and five replicates. The treatments tested were: 1 - control: without inoculant use; 2- seed treatment with $A$. brasilense; 3- seed treatment with algae extract; 4- seed treatment with co-inoculation (A. brasilense with $A$. nodosum). The evaluated characteristics were fresh leaf mass, fresh petiole mass, fresh root mass, fresh shoot mass, root/shoot ratio, leaf area, dry leaf mass, dry petiole mass, dry root mass, dry shoot mass and dry mass of the total plant. The largest arugula leaf area was obtained with co-inoculation of A. brasilense and A. nodosum. The highest root/shoot ratio was obtained in the treatment with the control. The highest dry mass of the total plants was obtained in the treatments with A. brasilense and co-inoculation. Co-inoculation of A. brasilense with A. nodosum is recommended.
\end{abstract}

Keywords: Eruca sativa. Co-inoculation. Diazotrophic. Phytoregulator. Bioregulator.

\section{TRATAMENTO DE SEMENTES DE RÚCULA COM ASCOPHYLLUM NODOSUM E AZOSPIRILLUM BRASILENSE EM VILHENA, RONDÔNIA}

\begin{abstract}
RESUMO: No estado de Rondônia são escassas as informações que buscam alternativas biológicas no cultivo da rúcula. Diante disso, objetivou-se avaliar as características agronômicas da rúcula em função da inoculação de sementes com Azospirillum brasilense, extrato de algas (Ascophyllum nodosum) e coinoculação (A. nodosum com A. brasilense) em Vilhena/RO. O experimento foi realizado no período de março a abril de 2018, na Faculdade da Amazônia, Vilhena, Rondônia. O delineamento experimental foi inteiramente casualizado com quatro tratamentos e cinco repetições. Os tratamentos testados foram: 1- testemunha: sem uso de inoculante; 2- tratamento das sementes com A. brasilense; 3- tratamento das sementes com extrato de algas; 4- tratamento das sementes com coinoculação (A. brasilense com A. nodosum). As características avaliadas foram massa verde das folhas, massa verde dos pecíolos, massa verde da raiz, massa verde aéreo total, proporção raiz/aéreo, área foliar, massa seca de folhas, massa seca dos pecíolos, massa seca da raiz, massa seca aéreo total, massa seca da planta total. A maior área foliar da rúcula foi obtida com a coinoculação do A. brasilense com A. nodosum. A maior proporção raiz/aéreo foi obtida no tratamento com a testemunha. A maior massa seca total das plantas foi obtida nos tratamentos com A. brasilense e coinoculação. Recomenda-se a coinoculação com A. brasilense com A. nodosum.
\end{abstract}

Palavras-chave: Eruca sativa. Coinoculação. Diazotróficas. Fitorregulador. Biorregulador.

\section{INTRODUCTION}

Arugula (Eruca sativa L.) belongs to the Brassicaceae family, and is an annual, small-sized, and fast-growing vegetable also known as Persian mustard. The crop presents a spicy taste and a pleasant

\footnotetext{
${ }^{1}$ FAMA- FACULDADE DA AMAZÔNIA
}

Nucleus,v.16,n.2,out.2019 
smell. Its origins is in the Mediterranean, and was introduced in Brazil by the Italian immigrants. The main form of arugula consumption is in salads and pizzas. This plant is rich in potassium, sulfur, iron, and vitamins $\mathrm{A}$ and $\mathrm{C}$, and also has digestive, diuretic, stimulant, laxative, detoxifying and anti-inflammatory properties (Freitas et al., 2017).

Biological nitrogen fixation (BNF) is the process in which diazotrophic bacteria capture nitrogen from the atmosphere and transforms it into assimilable nitrogen by plants. Bacteria of the genus Azospirillum perform BNF as well as help in hormones production, such as auxins, cytokinins and gibberellins, that favors greater root growth and consequently more nutrients and water absorption, leading to better fertilizers use and increased capacity of the plant to produce and support environmental stresses (HUNGRIA, 2011). A. nodosum, a Canadian seaweed, produces extracts with different growth regulators (cytokinins, auxins, gibberellins and betaines), macronutrients and micronutrients that can benefit plants (BERTOLDO et al., 2015).

Recently, several studies have been carried out to test the efficacy of Azospirillum brasilense and Ascophyllum nodosum in different crops, such as A. brasilense in soybean (ZUFFO et al., 2015), wheat (RODRIGUES et al., 2014 and VAZQUEZ et al., 2018), rice (GITTI et al., 2012), lettuce (LIMA et al., 2017), bean (VERONEZI et al., 2012) and maize (DARTORA et al., 2013). The algae extract (A. nodosum) chave been used in bean (BERNARDES et al., 2016), sweet potato (NEUMANN et al., 2017), soybean and sorghum (MELO et al., 2017), carrot (KASEKER et al., 2014) and rice (GROHS et al., 2012). The results were positive in the majority of these studies, indicating growth and production increase.

In the state of Rondônia, Brazil, there is no information on the use of bacteria of the genus Azospirillum brasilense and algae extract (Ascophyllum nodosum) in arugula. The investigation of these products influence on the crop is important, as sustainable alternatives that benefit the biological nitrogen fixation and composition of natural hormones that enhance plant development should be encouraged.

The objective of this study was to evaluate agronomic characteristics of arugula as a function of seed inoculation with Azospirillum brasilense, algae extract (Ascophyllum nodosum) and co-inoculation (A. brasilense with A. nodosum) in Vilhena, Rondônia, Brazil.

\section{MATERIAL AND METHOD}

The experiment was carried out from March to April, 2018 in protected environment covered with a 100 micron greenhouse plastic cover, surrounded by $50 \%$ shading material. The study was conducted at the Faculdade da Amazônia (FAMA), in the municipality of Vilhena, state of Rondônia, $12^{\circ} 59^{\prime} 22^{\prime \prime} \mathrm{S}$ and $58^{\circ} 45^{\prime} 51^{\prime \prime} \mathrm{W}$, with an altitude of $585 \mathrm{~m}$.

The 'Rúcula Selecta' was used, provided by 'Horticeres Seeds'. This cultivar is adapted to the Vilhena climatic conditions, and is the main cultivar cropped by local growers. The experiment was conducted in polyethylene containers with a capacity of $8 \mathrm{~L}$.

A 2:1 substrate was used, being two soil measurements collected at $0-0.20 \mathrm{~m}$ depth and one of earthworm humus (minhomax ${ }^{\circledR}$ ). The soil was classified as Dystrophic Yellow Red Latosol, with sandy loam texture (EMBRAPA, 1999), with the following chemical characteristics: $\mathrm{pH}\left(\mathrm{CaCl}_{2}\right)=5.0 ; \mathrm{Al}=0.00$ $\mathrm{cmol}_{\mathrm{c}} \mathrm{dm}^{-3} ; \mathrm{Ca}^{2+}+\mathrm{Mg}^{2+}=2.41 \mathrm{cmol}_{\mathrm{c}} \mathrm{dm}^{-3} ; \mathrm{K}^{+}=0.058 \mathrm{cmol}_{\mathrm{c}} \mathrm{dm}^{-3} ; \mathrm{P}=2.5 \mathrm{mg} \mathrm{dm}{ }^{-3} ; \mathrm{MO}=20.5 \mathrm{~g} \mathrm{dm}^{-3} ;$ areia $=590 \mathrm{~g} \mathrm{~kg}^{-1}$; silte $=104 \mathrm{~g} \mathrm{~kg}^{-1}$; argila $=306 \mathrm{~g} \mathrm{~kg}^{-1} ; \mathrm{CTC}=554 \mathrm{cmol}_{\mathrm{c}} \mathrm{dm}^{-3} ; \mathrm{V}(\%)=44.58$.

The experimental design was completely randomized with four treatments and five replicates. The seed treatments tested were: Treatment 1: control - without inoculant use; Treatment 2: Azospirillum 
brasilense; Treatment 3: seaweed extract (Ascophyllum nodosum); Treatment 4: A. brasilense coinoculation with algae extract (A. nodosum). Each pot represented one plot, totaling twenty experimental units. In each treatment, 150 seeds were used.

In treatment 1 , the chemical fertilization recommended for arugula was adopted, and pre-soaked with deionized water. In treatment 2 , the seeds were inoculated with $1.5 \mathrm{ml}$ of commercial inoculant containing A. brasilense at sowing; the dose indicated for maize was used, as there are no reference doses for arugula. The inoculant $A$. brasilense is a biological product in liquid form, which contains 200 million cells per $\mathrm{ml}$ of the strains (ABV5 and ABV6). In treatment 3 the algae extract product used was 'Ânimo Raiz'; the seeds were pre-soaked with $3.0 \mathrm{ml}$ of the commercial formulation dissolved in $1000 \mathrm{ml}$ of deionized water. For treatment 4, the co-inoculation was performed (A. brasilense with seaweed extract). Seven hours prior to sowing, the seeds were pre-soaked with $3.0 \mathrm{ml}$ of the commercial formulation of $A$. nodosum dissolved in $1000 \mathrm{ml}$ of deionized water. At the time of sowing the seeds were co-inoculated with $1.5 \mathrm{ml}$ of the commercial product containing A. brasilense.

The seeds were placed on germinating paper and moistened so that the solution was homogeneous between the seeds. The inoculation was performed seven hours before sowing.

Thirty seeds were sown per pot, and at nine days after sowing (DAS), when the seedlings were measuring on average $1.50 \mathrm{~cm}$, the first thinning was performed, leaving only 10 plants per pot; at 14 DAS, a second thinning was carried out leaving six plants per pot (PORTO et al., 2013).

Irrigation was performed daily, with an irrigation shift until the soil reaches 65 to $70 \%$ of the field capacity, according to Pereira et al. (1999). Weeds were removed so that only the arugula plants were kept in the pots.

The characteristics evaluated 30 days after emergence were: fresh leaf mass (FLM), dry leaf mass (DLM), fresh petiole mass (FPN), dry petiole mass (DPM), fresh root mass (FRM), dry root mass (DRM), fresh shoot mass (FSM), dry shoot mass (DSM), dry total plant mass (DTPM), leaf area (LA) as described by Daughtry (1990), and root/shoot ratio (R/S).

The results were submitted to analysis of variance and the means compared by the Tukey test at $5 \%$ probability.

\section{RESULT AND DISCUSSION}

There was a significant difference for the variables FLM, DLM, FPN, DPM, FSM, DSM, DTPM, LA and R/S. However, there was no difference for FRM and DRM (Table 1).

Table 1. Summary of variance analysis of ten agronomic characteristics of arugula cv. Selecta inoculated with A. brasilense, algae extract (A. nodosum) and co-inoculation (A. brasilense and A. nodosum).

\begin{tabular}{|c|c|c|c|c|c|c|c|}
\hline VS & DF & FLM & DLM & FPN & DPM & FRM & DRM \\
\hline $\mathrm{T}$ & 3 & $3406^{\text {*** }}$ & $28^{* *}$ & $668.8^{* * *}$ & $3.90^{* *}$ & $18.21^{\mathrm{ns}}$ & $0.34^{\mathrm{ns}}$ \\
\hline Residue & 16 & 79.72 & 0.98 & 30.98 & 0.20 & 10.96 & 0.74 \\
\hline $\mathrm{CV}(\%)$ & & 5.21 & 8.60 & 8.07 & 10.4 & 9.64 & 16.1 \\
\hline Mean & & 171.5 & 11.5 & 69.01 & 4.27 & 34.36 & 5.3 \\
\hline VS & $\mathrm{DF}$ & FSM & DSM & DTPM & LA & $\mathrm{R} / \mathrm{S}$ & \\
\hline $\mathrm{T}$ & 3 & $6942^{* *}$ & $55.2^{* *}$ & $55.2^{* *}$ & $433^{* *}$ & $0.037^{* * *}$ & \\
\hline Residue & 16 & 218.49 & 2.89 & 2.89 & 26.99 & 0.002 & \\
\hline $\mathrm{CV}(\%)$ & & 6.15 & 8.08 & 8.08 & 11.81 & 11.25 & \\
\hline Mean & & 240.51 & 21.05 & 21.05 & 43.97 & 0.43 & \\
\hline
\end{tabular}


The mean values for FLM, FPM, FRM, FSM, and LA of arugula inoculated with A. brasilense, algae extract and co-inoculation are described in Table 2. When analyzing the FLM, it was observed that the treatment that differed significantly from the others was the co-inoculation, which was $31.56 \%$ higher than the control. These results demonstrate that the leaves responded positively to co-inoculation.

For FPM, significant difference was detected in the treatments with co-inoculation and $A$. brasilense, with a mean of $30.77 \%$ higher in relation to the control. For FSM, there was a significant difference for the treatments with co-inoculation and A. brasilense; the control mean was $32 \%$ smaller than co-inoculation.

Co-inoculation improved the LA by 39\% compared to the control. The leaves are the arugula part that is most edible. Co-inoculation and A. brasilense did not differ.

Table 2. Average values for fresh leaf mass, fresh petiole mass, fresh root mass, fresh shoot mass and leaf area of arugula inoculated with $A$. brasilense, algae extract, and co-inoculation.

\begin{tabular}{lcccc}
\hline \multicolumn{1}{c}{ Treatments } & FLM & FPM & FSM (g) & \multicolumn{1}{c}{ LA } \\
cm $^{2}$
\end{tabular}

Means followed by the same lowercase letter in the column do not differ by the Tukey test at the 5\% probability level.

Co-inoculation and A. brasilense significantly differed for FSM (Table 3). The control treatment was significantly lower than the other treatments. There was an FSM increase of $34.39 \%$ when the seeds were co-inoculated in relation to the control.

The treatments co-inoculation and A. brasilense were superior for DSM, differing from the treatments with algae extract and the control. Similar results were found by Peters et al. (2018) evaluating growth promoters like A. nodosum in Arudo donax L., which did not verify increase in biomass and yield.

For R/S ratio, a significant difference between treatments was detected, with the control being $28.57 \%$ higher than the average of the others. Therefore, arugula 'Selecta' inoculated and co-inoculated presents greater shoot development in relation to the roots. The shoot increase may possibly have occurred because the products used are growth promoters that benefit aerial part of the plant. According to Taiz and Zeiger (2013), when there is an increase of auxins, the plants develop more the shoot in relation to the roots, because the root system is inhibited by the excess of this hormone.

Table 3. Average values for dry shoot mass, dry total plant mass, root/shoot ratio of arugula inoculated with A. brasilense, extract of algae, and co-inoculation.

\begin{tabular}{lccc}
\hline \multicolumn{1}{r}{ Treatments } & DSM & DTPM & R/S \\
\hline Control & $-12.03 \mathrm{c}$ & $17.05 \mathrm{~b}$ & $0.56 \mathrm{a}$ \\
A. brasilense & $17.82 \mathrm{a}$ & $23.16 \mathrm{a}$ & $0.44 \mathrm{~b}$ \\
Algae extract & $14.21 \mathrm{~b}$ & $19.67 \mathrm{~b}$ & $0.39 \mathrm{~b}$ \\
Co-inoculation & $19.12 \mathrm{a}$ & $24.34 \mathrm{a}$ & $0.37 \mathrm{~b}$ \\
\hline
\end{tabular}

Means followed by the same lowercase letter in the column do not differ by the Tukey test at the 5\% probability level. 
For DLM and DPM, co-inoculation and A. brasilense were also superior to the algae extract and the control. A 36\% increase in DLM was found comparing the co-inoculation with the control (Table 4).

No differences were observed for DRM. Although the two products used (A. brasilense and algae extract) provide substances that develop the root system, this effect was not noticed in arugula roots.

Table 4. Distribution of dry root mass, petiole and leaves of arugula cv. Selecta, at 30 days after emergence inoculated with A. brasilense, algae extract, and co-inoculation.

\begin{tabular}{lccc}
\hline \multicolumn{1}{c}{ Treatments } & DLM & DPM & DRM \\
\hline Control & $9 \mathrm{c}$ & $3 \mathrm{c}$ & $5 \mathrm{a}$ \\
A. brasilense & $13 \mathrm{a}$ & $5 \mathrm{a}$ & $6 \mathrm{a}$ \\
Algae extract & $10 \mathrm{~b}$ & $4 \mathrm{~b}$ & $5 \mathrm{a}$ \\
Co-inoculation & $14 \mathrm{a}$ & $5 \mathrm{a}$ & $5 \mathrm{a}$ \\
\hline
\end{tabular}

Means followed by the same lowercase letter in the column do not differ by the Tukey test at the $5 \%$ probability level.

No results were found in the current literature on A. brasiliense and A. nodosum co-inoculation. Therefore, this work becomes a reference in the subject. Comparisons with studies were related to $A$. brasilense and A. nodosum separetely. The A. nodosum applied alone in arugula seed treatment did not promote increment. However, when this product was co-inoculated with A. brasilense, the results were potentiated, as they contain amino acids and plant hormones, which favored the greater yield.

Ferrazza et al. (2010) verified higher production in soybean seed-inoculated with A. nodosum, demonstrating the efficiency of the product, as contains amino acids and plant hormones, which possibly contributed to the better plant development. Kaseker et al. (2014) verified a beneficial effect for algae extract (A. nodosum) in carrot cropping, providing larger root diameter, greater shoot development and, consequently, higher yield.

Co-inoculated and inoculated plants with A. brasilense produced larger fresh and dry mass. Similar results were reported by Dartora et al. (2013), that verified higher corn production when inoculated via seed with bacteria of the genus Azospirillum, providing increases in dry mass and yield in relation to the control. In a study conducted by Rodrigues et al. (2014), A. brasilense exerted a beneficial effect on wheat, increasing the leaves dry matter.

Lima et al. (2017) studied A. brasilense and root growth promoters in lettuce in Colorado Rondônia, Brazil, and verified that there was a significant effect of $A$. brasilense application without root growth promoter, in relation to height and shoot development.

\section{CONCLUSIONS}

The largest leaf area in arugula culture was obtained with co-inoculation of Azospirillum brasilense with algae extract (Ascophyllum nodosum).

The highest root/shoot ratio was obtained in the control.

The highest dry total plant mass was obtained in the treatments Azospirillum brasilense and coinoculation.

The inoculation indicated for arugula 'Selecta' is the co-inoculation of Azospirillum brasilense with algae extract (Ascophyllum nodosum). 


\section{REFERENCES}

BERNARDES, R. F. B.et al. Establishment of DRIS indices and foliar nutrient levels for corn plants fertilized with various nitrogen doses and source materials associated with marine alga Lithothamnium. Scientific Electronic Archives, v. 9, n. 4, p. 26-33, 2016.

BERTOLDO, J. G. et al. Alternativas na fertilização de feijão visando a reduzir a aplicação de N-ureia. Pesquisa Agropecuária Tropical, v. 45, n. 3, p. 348-355, 2015. DOI: https://doi.org/10.1590/1983$40632015 \mathrm{v} 4534885$

DAUGHTRY, C. S. T.; GOEL, N. S.; NORMAN, J. M. Instrumentation for studying vegetation canopies for remote sensing in optical and thermal infrared regions. Remote sensing reviews, v. 5, n. 1, p. 45-60, 1990.

DARTORA, J. et al. Adubação nitrogenada associada à inoculação com Azospirillum brasilense e Herbaspirillum seropedicae na cultura do milho. Revista Brasileira de Engenharia Agrícola e Ambiental, Campina Grande, v. 17, n. 10, p. 1023-1029, 2013. DOI: https://doi.org/10.1590/s141543662013001000001

FERRAZZA, D.; SIMONETTI.; MOURÃO, A. P. M. Uso de extrato de algas no tratamento de semente e aplicação foliar, na cultura da soja. Revista Cultivando o Saber, v. 3, n. 2, p. 48-57, 2010.

FREITAS, E. M. et al. Arugula production as a function of irrigation depths and potassium fertilization. Revista Brasileira de Engenharia Agrícola e Ambiental, Campina Grande, v. 21, n, 3, p. 197-202, 2017. DOI: http://dx.doi.org/10.1590/1807-1929/agriambi.v21n3p197-202

GROHS, M. et al. Desempenho de cultivares de arroz com uso de reguladores de crescimento, em diferentes sistemas de cultivo. Pesquisa Agropecuária Brasileira, v. 47, n. 6, p. 776-783, 2012. DOI: https://doi.org/10.1590/s0100-204x2012000600007

GITTI, D. D. C. et al. Coberturas vegetais, doses de nitrogênio e inoculação de sementes com Azospirillum brasilense em arroz de terras altas no sistema plantio direto. Revista Bragantia, v. 71, n. 4, p. 509-517, 2012. DOI: https://doi.org/10.1590/s0006-87052013005000002

HUNGRIA, M. Inoculação com Azospirillum brasilense: inovação em rendimento a baixo custo Londrina: Embrapa Soja, 36 p. 2011. (Documentos, 325).

KASEKER, J. F. et al. Alteração do crescimento e dos teores de nutrientes com utilização de fertilizante organomineral em cenoura. Revista Ceres, v. 61, n. 6, p. 964-969, 2014. DOI:

https://doi.org/10.1590/0034-737x201461060011

LIMA, A. A. et al. Eficiência da inoculação de Azospirillum brasilense associado com enraizador no crescimento e na produção de alface. Revista Verde de Agroecologia e Desenvolvimento Sustentável, v. 12, n. 2, p. 233-240, 2017. DOI: https://doi.org/10.18378/rvads.v12i2.4300

MELO, T.A. et al. Produtos naturais disponíveis comercialmente induzem o acúmulo de fitoalexinas em cotilédones de soja e mesocótilos de sorgo. Summa Phytopathologica, v. 43, n. 3, p. 205-211, 2017. DOI: https://doi.org/10.1590/0100-5405/167358

NEUMANN, E. R. et al. Produção de mudas de batata doce em ambiente protegido com aplicação de extrato de Ascophyllum nodosum. Horticultura Brasileira, v. 35, n. 4, p. 490-498, 2017. DOI: https://doi.org/10.1590/s0102-053620170404

PETERS, H. F. Y. A.; EMILY, G.; PAPADOPOULOS, J. K. V. Effects of growth-promoters on the productivity of Arundo donax L. (NileFiber ${ }^{\mathrm{TM}}$ ) as a purpose-grown biofuel feedstock in Nova Scotia. Canadian Journal of Plant Science, v. 98, n. 2, p. 380-394, 2018. DOI: https://doi.org/10.1139/cjps2016-0413 
PEREIRA, A. J. et al. A. Efeito dos níveis de reposição e frequência de irrigação sobre a produção e qualidade do rabanete. Revista Brasileira de Engenharia Agrícola e Ambiental, v. 3, n. 1, p. 117-120, 1999. DOI: https://doi.org/10.1590/1807-1929/agriambi.v3n1p117-120

PORTO, R. A. et al. Adubação potássica em plantas de rúcula: Produção e eficiência no uso da água. Revista Agro@mbiente On-line, v. 7, n. 1, p. 28-35, 2013. DOI: https://doi.org/10.18227/19828470ragro.v7i1.760

RODRIGUES, L. F. et al. Características agronômicas do trigo em função de Azospirillum brasilense, ácidos húmicos e nitrogênio em casa de vegetação. Revista Brasileira de Engenharia Agrícola e Ambiental, v. 18, n. 1, p. 31-37, 2014. DOI: https://doi.org/10.1590/s1415-43662014000100005

TAIZ, L.; ZEIGER, E. Fisiologia Vegetal. 5. ed. Porto Alegre: Editora Artemed, 2013. 954 p.

VAZQUEZ et al. Inoculação com Azospirillum brasilense e tratamento de semente em trigo irrigado no noroeste paulista. Nucleus, v.15, n.2, 2018. http://dx.doi.org/10.3738/1982.2278.2862

VERONEZI, S. D. F. et al. Co-inoculação de rizóbio e Azospirillum brasilense em feijoeiro (Phaseolus vulgaris L.). Cadernos de Agroecologia, v. 7, n. 2, p. 1-5, 2012.

ZUFFO, A. M. et al. Coinoculação de Bradyrhizobium japonicum e Azospirillum brasilense na cultura da soja. Revista de Ciências Agrárias, v. 38, n. 1, p. 87-93, 2015. 